BJHS: Themes 4: 55-77, 2019. C British Society for the History of Science 2019. This is an Open Access article, distributed under the terms of the Creative Commons Attribution-NonCommercialNoDerivatives licence (http://creativecommons.org/licenses/by-nc-nd/4.0/), which permits noncommercial re-use, distribution, and reproduction in any medium, provided the original work is unaltered and is properly cited. The written permission of Cambridge University Press must be obtained for commercial re-use or in order to create a derivative work.

doi:10.1017/bjt.2019.12 First published online 2 September 2019

\title{
Spencer's double: the decolonial afterlife of a postcolonial museum prop
}

\author{
EMMA KOWAL*
}

\begin{abstract}
In the mid-1990s, staff at Museum Victoria planned the new Melbourne Museum. The Indigenous gallery was a major focus at a time when many museums around the world forged new ways of displaying Indigenous heritage. Named Bunjilaka (a Woiwurrung word meaning 'place of Bunjil', referring to the ancestral eaglehawk), the permanent Indigenous exhibit was a bold expression of community consultation and reflexive museum practice. At its heart was a life-size model of Baldwin Spencer, co-author of the classic anthropological monograph The Native Tribes of Central Australia (1899). When Bunjilaka was replaced with a wholly Indigenous-designed exhibit of Aboriginal Victoria in 2011, the model was informally retained by museum staff. Initially sitting awkwardly on a trolley in a narrow room where objects were processed for accession, Spencer himself remained unrecorded in any database. With no official existence but considerable gravity, he ended up housed in the secret/sacred room, surrounded by restricted objects that Spencer the man had collected. This article traces Spencer's journey from a post-colonial pedagogical tool to a transgressive pseudosacred object in an emerging era of decolonial museology. I argue that Spencer's fate indicates a distinct period of post-colonial museology $(c .1990-2010)$ that has ended, and illustrates how the shifting historical legacies of science operate in the present.
\end{abstract}

In a dark, dark wood there was a dark, dark house;

And in the dark, dark house there was a dark, dark room;

And in the dark, dark room there was a dark, dark cupboard;

And in the dark, dark cupboard there was a dark, dark shelf;

And on the dark, dark shelf there was a dark, dark box;

And in the dark, dark box there was a ... ghost!

Traditional English children's story

This essay is about a ghost in the dark, but it begins in the piercing light of Alice Springs, Central Australia, on 18 May 1901 (Figure 1). Walter Baldwin Spencer (1860-1929), Foundation Professor of Biology at the University of Melbourne and groundbreaking

Alfred Deakin Institute for Citizenship and Globalisation, Deakin University, 221 Burwood Hwy, Burwood, Victoria, 3125, Australia. Email: Emma.kowal@deakin.edu.au.

Thanks to Simon Werrett, Ann Kakaliouras, Jenny Bangham, Boris Jardine, Tony Birch, Philip Batty and two anonymous reviewers for their comments on earlier versions of this paper. My research is supported by an Australian Research Council Future Fellowship (FT160100093). 


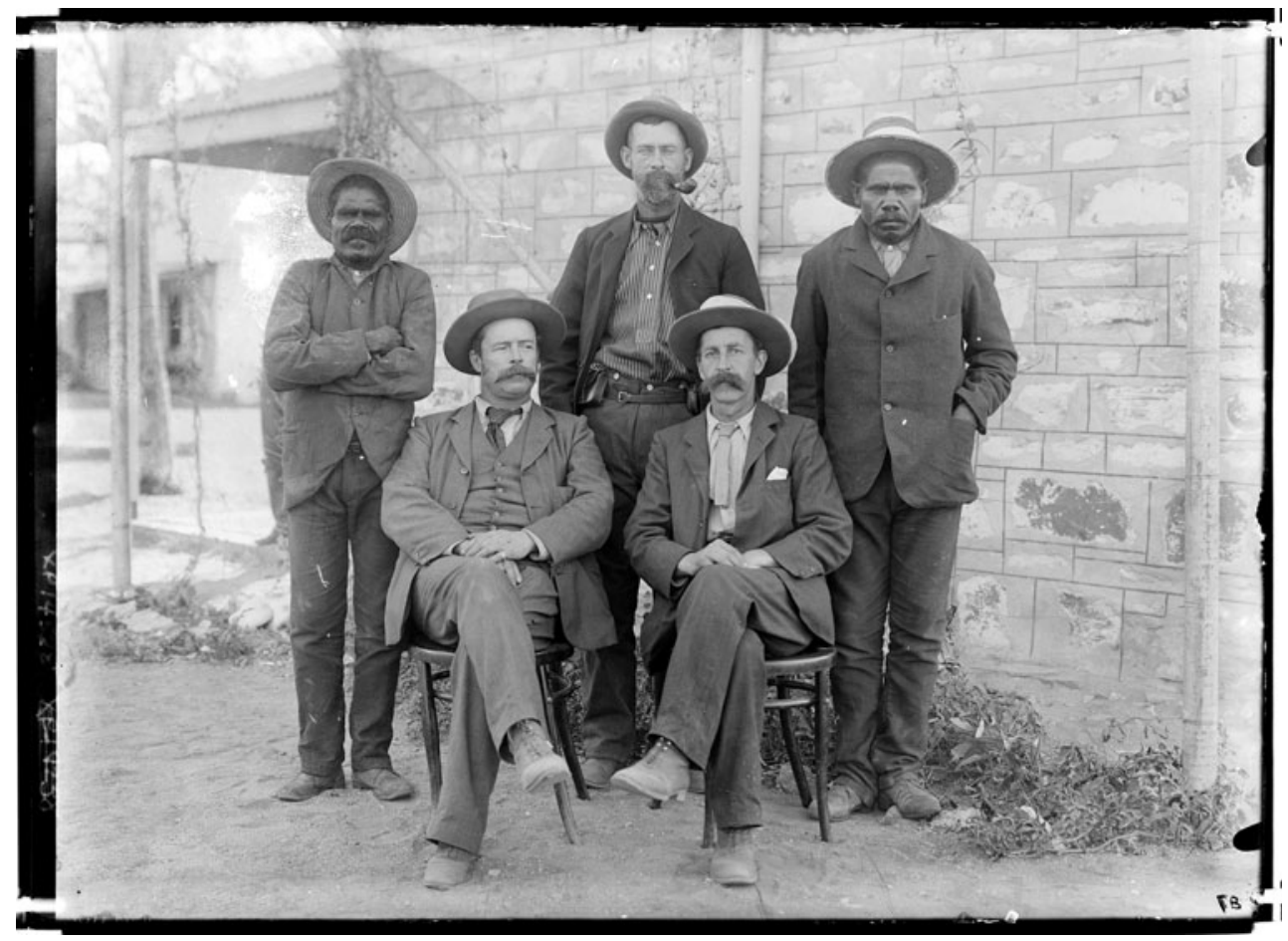

Figure 1. Photograph of 1901-1902 expedition party, Alice Springs, 18 May 1901. Back row, left to right: Erlikiliakirra (Jim Kite), Harry Chance, Purula (Parunda). Front row, left to right: Francis James Gillen, Walter Baldwin Spencer. Source: Museum Victoria.

anthropologist of Aboriginal Australia, sits on a bentwood chair and stares into the lens. Beside him, on another bentwood chair, is his long-time collaborator and Alice Springs stationmaster, Francis Gillen (1855-1912). Gillen gazes towards the left of the frame. Their legs cross towards each other, the body language reflecting their close friendship. The image was captured outside Francis Gillen's house at the Alice Springs Telegraph Station near the start of the 1901-1902 expedition. Two days earlier, Gillen's latest child had been born, a son, named Spencer Gillen to honour his friend. In a standard visual trope of colonial expedition photography, the supporting actors stand behind: Trooper Harry Chance, expedition cook and driver, flanked by two Aboriginal 'assistants' from Charlotte Waters, Erlikiliakirra and Purula, who handled the twenty horses and at times acted as interpreters. Trooper Chance's regular wage was paid by the expedition, amounting to two hundred pounds for the year: Erlikiliakirra and Purula worked for rations. ${ }^{1}$

1 This detail about Spencer and Gillen and others mentioned in this essay derives from the definitive biography, Derek John Mulvaney and J.H. Calaby, So Much That Is New: Baldwin Spencer, 1860-1929, a Biography, Carlton: Melbourne University Press, 1985. See also Derek John Mulvaney, Howard Morphy 
This small party had set out from Adelaide two months earlier on a year-long anthropological expedition to the Northern Territory and Queensland. In the wake of the instant success of Spencer and Gillen's 1899 book The Native Tribes of Central Australia, celebrated Scottish anthropologist Sir James Frazer led efforts by leading UK scholars to convince the Victorian and South Australian premiers to support Gillen and Spencer's 'work among the tribes who still remain to be examined'. 2 They set off from Oodnadatta, the end of the railway line north of Adelaide, laden with food, logistical and scientific equipment, and supplies to offer Aboriginal people in exchange for information - flour, sugar, pipes and tobacco, and hundreds of steel axes and knives. They returned with plentiful ethnographic notes, thousands of sacred and profane artefacts, five hundred photographs, thousands of feet of film footage, and two dozen cylinders of phonograph recordings.

Baldwin Spencer had grown up in Manchester in the 1860s and 1870s and studied biology at Oxford before moving to Australia for his chair at the University of Melbourne in 1887 at the age of twenty-seven. Among his many prominent roles in the fledgling Melbourne scientific scene, he became honorary director of the National Museum of Victoria (now Museum Victoria) in 1899, a position he held for nearly thirty years. He was responsible for the acquisition of several thousand Aboriginal objects, including many that he collected himself. He sent numerous pieces of Aboriginal cultural heritage overseas, bartering with museums to build Melbourne's international collections, including, famously, a Samoyed sledge from Leningrad complete with harnessed reindeer and traditional costumes. He pioneered an arrangement with the chief commissioner of police whereby any human remains in their possession that were thought to be Aboriginal were deposited in the museum, swelling the museum's collection of skeletal material. ${ }^{3}$ Today, the Spencer and Gillen collection at Museum Victoria consists of nine hundred manuscript items, 1,500 ethnographic items, and many other photographs and film and sound recordings. ${ }^{4}$

Spencer enjoyed over forty years based in Melbourne and a lively career in biology, anthropology, museology and Aboriginal affairs until his death while conducting fieldwork in Tierra del Fuego in 1929. During his lifetime (and for half a century afterwards) his scientific achievements were seen in wholly positive terms. He had put the customs of

and Alison Petch (eds.), 'My Dear Spencer': The Letters of F.J. Gillen to Baldwin Spencer, Melbourne: Hyland House, 1997; Howard Morphy, 'More than mere facts: repositioning Spencer and Gillen in the history of anthropology', in S.R. Morton and D.J. Mulvaney (eds.), Exploring Central Australia: Society, Environment and the 1894 Expedition, Chipping North, NSW: Surrey Beatty, 1996, pp. 135-149; on expedition photography see James R. Ryan, Picturing Empire: Photography and the Visualization of the British Empire, Chicago: The University of Chicago Press, 1997.

2 Letter, Frazer to Spencer, 4 June 1900, cited in Mulvaney and Calaby, op. cit. (1), p. 189. Kuklick has masterfully explored the impact of The Native Tribes of Central Australia on European scholarship and Australian policy. See Henrika Kuklick, "Humanity in the chrysalis stage": Indigenous Australians in the anthropological imagination, 1899-1926', BJHS (2006) 39(143), pp. 535-568; Baldwin Spencer and F.G. Gillen, The Native Tribes of Central Australia, New York: Dover Publications, 1968 (first published 1899).

3 Mulvaney and Calaby, op. cit. (1), pp. 249-254.

4 Australian National University et al., Spencer and Gillen: A Journey through Aboriginal Australia, at http://spencerandgillen.net, accessed 8 March 2018. 
Australian 'natives' on the world stage, salvaged countless priceless artefacts, and was instrumental in the development of remote reserves and urban compounds where Aboriginal people could be protected from frontier violence and be supported to become self-sufficient: all progressive goals for the time.

My story of Spencer's passage from the harsh light of Alice Springs into the dark requires that we focus not on the man himself, but on his 'doubles'. By 'doubles' I mean images, shadows and other likenesses and representations of the self - in this case, Spencer's photographic image and, principally, a model of Spencer we will meet shortly. My discussion below of Spencer's doubles draws on psychoanalytic theories of the double. Doubling is an inexhaustibly rich topic in psychoanalysis, but two main lines of scholarship are useful for my purposes - Freud's notion of the 'uncanny' and the work of his close colleague Otto Rank on the 'double'. ${ }^{5}$ Each of these notions of the double is relevant to different parts of the story I tell below.

In The Double: A Psychoanalytical Study (1914), Rank draws on anthropology and literature to make a wide-ranging argument that doubles - in the form of doppelgängers, shadows, spirits or ghosts - function as a vessel for negative feelings we harbour about ourselves. ${ }^{6}$ Projecting negative thoughts and feelings onto the double enables self-love to be maintained. Although some degree of this psychic mechanism is necessary to human flourishing, it can lead to excessive narcissism if we disavow too many of our self-doubts and repress the inevitable contradictions between what we wish we were and what we really are. Like the famous portrait of Dorian Gray in the locked room of Oscar Wilde's 1891 story, a double absorbs negative qualities to preserve the original - in that case, protecting Dorian Gray from the process of ageing and the consequences of immorality. I will argue that, in the early twenty-first century, a double of Spencer - enclosed not in an attic but in a glass case - became a receptacle for negative feelings that some white people felt towards colonialism.

Freud's famous 1919 essay on the 'uncanny' argues that a thing is experienced as uncanny when it recalls something that was once familiar to us but that we have repressed. The uncanny is closely related to the 'double'. Building on Rank's work, Freud notes that the double functions as a receptacle for undesirable (or unattainable) aspects of the ego as part of normal psychic development. However, if those qualities projected onto the double are repressed, doubles can become the source of uncanny feelings: 'The double has become an image of terror, just as, after the collapse of their

5 I am aware that pursuing theories of the double to understand Spencer's double is complicated by the fact that the relationships I primarily attempt to explain are those between non-indigenous people and Spencer's double, not between Spencer himself and his double. However, I contend the theories are still useful to understand Spencer's double as a 'double' of non-indigenous people in the sense that he stands in for colonial science and negative aspects of non-indigenous identities more broadly. Otto Rank, The Double: A Psychoanalytical Study, London: Karnac, 1989 (first published 1971). See also Rank, 'The double as immortal self', in Rank, Beyond Psychology, Camden, NJ: Haddon Craftsmen, 1941. Sigmund Freud, 'The "uncanny"' (1919), in Freud, The Standard Edition of the Complete Psychological Works of Sigmund Freud, vol. 17 (1917-1919): An Infantile Neurosis and Other Works, London: Hogarth, 1925, pp. 219252. Note that Rank and Freud, among many European theorists of the time, were influenced by Spencer's ethnography.

6 Rank, The Double, op. cit. (5). 
religion, the gods turned into demons.' This shift to the 'uncanny' is a result of repression, particularly of earlier stages (of life or of evolution) that we believe we have moved beyond: the uncanny is 'something which ought to have remained hidden but has come to light'. ${ }^{7}$ I will argue that after Spencer's double was evicted from its case in an attempt to repress colonialism, it shifted from a Rankian receptacle to an uncanny ghost.

In what follows, I hope to illustrate what the concept of the double might offer to historians. However, my approach to Spencer and his doubles is not wholly historical. I write neither as a historian of Baldwin Spencer, nor as a scholar of museum studies, but as an anthropologist of science, indigeneity and racial politics in Australia. I have come to the history of science and museums through a concern with how biological knowledge about Indigenous people is created, circulated, and used by different people for particular political, social or moral ends. Although my past work has predominantly drawn on ethnographic study of researchers who make knowledge about Indigenous people, history was always a prominent actor.

Most scientists who work with Australian Indigenous people have a strong historical consciousness. As the health researcher and historian of Indigenous health research David Thomas puts it, they are unlikely to know any details of 'past' research (usually meaning anything prior to the 1980s) but still share a 'vague certainty' that it was morally corrupt and definitively 'racist'. ${ }^{8}$ My ethnography has confirmed that those working in Indigenous fields, and 'progressive' or 'anti-racist' Australians in general, take great pains to distance themselves from their predecessors. ${ }^{9}$ In certain settler colonies, history is routinely evoked by nations and concerned citizens who wish to reconcile with the crimes of the colonial past and their impact on present-day Indigenous populations, a movement influenced by and tied to post-colonialism. ${ }^{10}$ The history of scientific research is often considered by Indigenous and post-colonial scholars to be amongst the worst parts of colonial history: research is 'a dirty word' for Indigenous people. $^{11}$

7 Freud, op. cit. (5), pp. 236, 241.

8 David P. Thomas, Reading Doctors' Writing: Race, Politics and Power in Indigenous Health Research, 1870-1969, Canberra: Aboriginal Studies Press, 2004, p. 2.

9 My work on scientists and health researchers working on Indigenous communities and data has included Emma Kowal, 'Orphan DNA: Indigenous samples, ethical biovalue and postcolonial science', Social Studies of Science (2013) 43(4), pp. 578-598; Kowal, Trapped in the Gap: Doing Good in Indigenous Australia, New York and London: Berghahn, 2015.

10 Important works on reconciliation and historical consciousness in Australia include Sara Ahmed, 'The politics of bad feeling', Australian Critical Race and Whiteness Studies Association Journal (2005) 1(1), pp. 72-85; Bain Attwood, 'Unsettling pasts: reconciliation and history in settler Australia', Postcolonial Studies (2005) 8(3), pp. 243-259; Miranda Johnson, 'Reconciliation, indigeneity, and postcolonial nationhood in settler states', Postcolonial Studies (2011) 14(2), pp. 187-201; Anthony Moran, 'What settler Australians talk about when they talk about Aborigines: reflections on an in-depth interview study', Ethnic and Racial Studies (2009) 32(5), pp. 781-801; A. Dirk Moses, 'Official apologies, reconciliation, and settler colonialism: Australian indigenous alterity and political agency', Citizenship Studies (2011) 15(2), pp. 145159.

11 Linda Tuhiwai Smith, Decolonizing Methodologies, Research and Indigenous Peoples, 2nd edn, London and New York: Zed Books Ltd, 2012. 
Although this essay begins with Spencer himself - or at least his photographic image its real focus is the role of the history of science in the post-colonial narratives (and, as I will argue, the subsequent decolonial narratives) of late twentieth- and early twenty-firstcentury Australia. I experienced this period first-hand as an Indigenous solidarity activist while a student at the University of Melbourne in the 1990s, and as a medical doctor, health researcher and anthropologist in Indigenous communities in the north of Australia in the 2000s. In the social worlds I inhabited, the history of scientific research in Indigenous Australian populations was frequently invoked as something to be embarrassed about, ${ }^{12}$ and to distinguish ourselves from. ${ }^{13}$

In this essay, it is Spencer's double that is the vessel for the embarrassing scientific past that progressive Australians of the 1990s and 2000s - specifically, in this case, museum visitors and museum staff - often felt bad about. In fact, by the early 1970s Spencer had already become a focus for negative feelings about the man and what he stood for: white, colonial, masculine domination of the Indigenous 'other' ${ }^{14}$ His reference to Aboriginal people as 'naked, howling savages' in The Northern Tribes of Central Australia was not lost on critics of colonialism who identified him with an evolutionary anthropology that sought to study Aboriginal culture before its inevitable extinction. ${ }^{15}$ As chief protector of Aborigines in the Northern Territory from 1911, Spencer advocated for the abduction of so-called 'half-caste' Aboriginal children 'for their own good', a practice that continued until the 1970s and produced what is now known as the Stolen Generations. ${ }^{16}$

This tide of sentiment against the prodigious white collectors of anthropology impacted on the museums that many of them contributed to. Motivated by Indigenous activists both within and outside the museum sector, and by the writings

12 On embarrassment and the global history of biological anthropology see Susan Lindee and Ricardo Ventura Santos, 'The biological anthropology of living human populations: world histories, national styles, and international networks: an introduction to Supplement 5', Current Anthropology (2012) 53(S5), pp. S3-S16.

13 Key literature on the history of scientific research on Indigenous Australians includes Warwick Anderson, The Cultivation of Whiteness: Science, Health and Racial Destiny in Australia, Melbourne: Melbourne University Press, 2002; Anderson, 'Hermannsburg, 1929: turning Aboriginal "primitives" into modern psychological subjects', Journal of the History of the Behavioral Sciences (2014) 50(2), pp. 127-147; Bronwen Douglas and Chris Ballard (eds.), Foreign Bodies: Oceania and the Science of Race 1750-1940, Canberra: ANU E Press, 2008; Ross L. Jones and Warwick Anderson, 'Wandering anatomists and itinerant anthropologists: the antipodean sciences of race in Britain between the wars', BJHS (2015) 48(1), pp. 1-16; Nicolas Peterson, Lindy Allen and Louise Hamby (eds.), The Makers and Making of Indigenous Australian Museum Collections, Carlton: Melbourne University Publishing, 2008; Libby Robin, 'Collections and the nation: science, history and the National Museum of Australia', Historical Records of Australian Science (2003) 14(3), pp. 251-289; Paul Turnbull, Science, Museums and Collecting the Indigenous Dead in Colonial Australia, Cham: Palgrave Macmillan, 2017.

14 For example, Spencer features in Frank S. Steven's three-volume study, Frank S. Stevens, Racism, the Australian Experience: A Study of Race Prejudice in Australia, New York: Taplinger Publishing, 1972.

15 Although note that Howard Morphy has argued that the now-infamous phrase 'naked howling savages' was included at the behest of Sir James Frazer and is not representative of Spencer's views of Indigenous people. Howard Morphy, 'Gillen: man of science', in Mulvaney, Morphy and Petch, op. cit. (1), pp. $23-51$.

16 See Human Rights and Equal Opportunity Commission, Bringing them Home: Report of the National Inquiry into the Separation of Aboriginal and Torres Strait Islander Children from Their Families, Canberra: Human Rights and Equal Opportunity Commission, 1997. 
of post-colonial scholars such as Edward Said, Homi Bhabha and Gayatri Spivak, scholars of museum studies and museum practitioners in settler colonial countries around the world asked questions about museums' colonial legacies and the possibility for museums to stimulate more positive cultural shifts towards inclusion and recognition, a movement often called the 'new museology'. ${ }^{17}$ Important signs of these shifts include the new Museum of New Zealand, Te Papa, that was legislated in 1992 and opened in 1998, and the National Museum of the American Indian, legislated in 1989 and opened in 2004. ${ }^{18}$ As we will see, Spencer's museum was part of this shift. Museum Victoria went through a major redevelopment phase in the 1990s in the lead-up to the opening of a new museum building in the year 2000. It is within this political context that Spencer's double shifted from the natural light of Central Australia to the artificial light of a museum exhibit.

The concepts of 'post-colonial' and 'decolonial' are important to the arguments I make below about the ends of scientific collectors and their collections. I draw a distinction between post-colonial and decolonial museology on historical and theoretical grounds, while acknowledging that the relationship between the two concepts is contested and varies in different contexts. ${ }^{19}$

Post-colonial studies is a multidisciplinary body of scholarship that examines the impacts and legacies of colonialism. While works identified as seminal post-colonial texts span the twentieth century, as an academic movement it gained momentum in the 1990s and was in part a merging of scholars who identified with subaltern studies and Commonwealth literary studies. Decolonialization or decoloniality, influenced primarily by Latin American scholarship, ${ }^{20}$ also has a long history, but has come into its own as an academic movement in the last decade. For example, the first journal featuring the term - Decolonization: Indigeneity, Education and Society - was launched in 2012, and the term 'decolonial studies' is only just emerging. As I explore further below, calls to 'decolonize the museum' have accompanied this 'decolonial turn'. ${ }^{21}$

17 See Peter Vergo, The New Museology, London: Reaktion Books, 1989; Tony Bennett, The Birth of the Museum: History, Theory, Politics, London: Routledge, 1995; Ivan Karp and Steven Lavine, Exhibiting Cultures: The Poetics and Politics of Museum Display, Washington, DC: Smithsonian Institution Press, 1991; T.J. Barringer and Tom Flynn, Colonialism and the Object: Empire, Material Culture, and the Museum, London: Routledge, 1998. On the new museology in the region see Chris Healy and Andrea Witcomb (eds.), South Pacific Museums: Experiments in Culture, Clayton, Victoria: Monash University Press, 2006.

18 See William J. Tramposch, 'Te Papa: reinventing the museum', Museum Management and Curatorship (1998) 17(4), pp. 339-350; Amanda J. Cobb and Amy Lonetree, The National Museum of the American Indian: Critical Conversations, Lincoln: University of Nebraska Press, 2008.

19 For example, Gurminder Bhambra has argued that post-colonial studies and decolonial scholarship are not in opposition to each other, but rather reflect two different communities of scholars with different major geographical referents: India for postcolonialism, and Latin America for decoloniality. See Gurminder K. Bhambra, 'Postcolonial and decolonial dialogues', Postcolonial Studies (2014) 17(2), pp. 115-121.

20 See, for example, Walter Mignolo, The Darker Side of Western Modernity: Global Futures, Decolonial Options, Durham, NC: Duke University Press, 2011.

21 The novelty of calls to decolonize the museum is illustrated by the fact that the author of the touchstone monograph for decolonizing the museum, Amy Lonetree's Decolonizing Museums: Representing Native America in National and Tribal Museums (Chapel Hill: University of North Carolina Press, 2012), does not 
Historians of science are likely to be familiar with post-colonialism through the work of Warwick Anderson, Kapil Raj, Suman Seth, Joanna Radin, Gyan Prakash and others. The concepts of decolonization and decoloniality may be less familiar, although I am certain a 'decolonial' history of science will soon emerge. ${ }^{22}$ One feature of the 'decolonial turn' is its frequent opposition to 'post-colonialism'. Science and technology studies is among the many academic disciplines where arguments for 'decolonality' and against 'post-colonialism' have recently been made. ${ }^{23}$ Decoloniality scholars and activists critique the concept of post-colonialism as not going far enough to 'undo' colonialism, and as inadequate for analysing settler colonialism. ${ }^{24}$

My interest here is neither to advocate for decoloniality nor to defend post-colonialism. Rather, they serve as background for my argument that over the last few years, at least in settler colonies, a mode of collection and display best described as 'post-colonial' has been supplanted by another mode best described as 'decolonial'. Post-colonial museology refigured the museum as a 'contact zone' in which multiple voices should be recognized and reflected. ${ }^{25}$ This was a space where historians of science had clear pedagogic, exhibitionary and epistemological roles. ${ }^{26}$ In the era of 'decolonial museology' emerging in settler colonies, only Indigenous voices (including Indigenous historians of science) are authorized to produce knowledge, and other perspectives on the history of science and the history of museums are strategically de-emphasized.

The fate of Spencer's double after he left his museum exhibit in 2011 was intimately connected with this transition in museum practice. The narrative below interweaves archival, ethnographic, historical and cultural analyses to describe and make sense of Spencer's post-exhibition journey from an illuminated glass case to a dark restricted room, deep in the museum. This story of the uncanny end of an unusual museum object illustrates how the decolonial turn, like all cultural shifts, may have unintended side effects. Despite efforts to expunge symbols of colonial knowledge and power from museums, some ghosts refuse to be silenced.

This is an unorthodox story of collection in more than one sense. First, it is the story of how a collector was ironically collected when the museum he previously led reflexively

use the word 'decolonize' once in a 2008 collection she edited although the word 'postcolonial' appears many times in the earlier book.

22 As indicated by increasing discussion of 'decolonizing science' and the American Historical Review's recent commitment to decolonize itself after a controversial book review was published in 2017. See Alex Lichtenstein, 'Decolonizing the AHR', American Historical Review (2018) 123(1), pp. xiv-xvii.

23 Kristina Lyons, Juno Salazar Parreñas and Noah Tamarkin, 'Engagements with decolonization and decoloniality in and at the interfaces of STS', Catalyst: Feminism, Theory, Technoscience (2017) 3(1), pp. 1-47; Sandra Harding, 'Latin American decolonial social studies of scientific knowledge: alliances and tensions', Science, Technology and Human Values (2016) 41(6), pp. 1063-1087.

24 Ramón Grosfoguel, 'The epistemic decolonial turn', Cultural Studies (2007) 21(2-3), pp. 211-223; Nelson Maldonado-Torres, 'Thinking through the decolonial turn: post-continental interventions in theory, philosophy, and critique. An introduction', Transmodernity (2011) 1(2), at https://escholarship.org/uc/item/ 59w8j02x; Eve Tuck and K. Wayne Yang, 'Decolonization is not a metaphor', Decolonization: Indigeneity, Education \& Society (2012) 1(1), pp. 1-40.

25 James Clifford, 'Museums as contact zones', in Clifford, Routes: Travel and Translation in the Late Twentieth Century, Cambridge, MA: Harvard University Press, 1997, pp. 188-219.

26 Many thanks to an anonymous reviewer for this useful formulation. 
interpreted his ambivalent legacy by putting his double in a glass case. Second, it is the story of how a prop - an item that was never intended to be part of the museum collection - ended up being collected, if only in an informal, unregulated fashion. Third, it is the story of the end of a mode of collecting, or rather the end of two subsequent modes of collecting: colonial and post-colonial. Spencer in a glass case was intended to signify the end of exploitative, colonial relations between Indigenous people and the Western knowledge makers who collected their objects. I will argue that Spencer's later decommissioning marked the end of a 'post-colonial' mode of museology and the beginning of a decolonial period of collecting and displaying. Finally, his post-exhibition life as a highly problematic object that refused to end raises questions about the opportunities and limits of decolonial practice in museums and in historical scholarship.

\section{Finding Spencer}

At an anthropology conference a few years ago, I heard a strange story. It was told by Philip Batty, senior curator of Central Australian collections at Museum Victoria. Philip had spent part of the 1970s and all of the 1980s in Central Australia as a schoolteacher in a remote community and then co-director of a newly established Aboriginal media organization in Alice Springs. He later settled in Melbourne and began working at the museum in the late 1990s, a time when plans were well under way for the opening of the new Melbourne Museum. The revamped museum included an extensive permanent Indigenous exhibit called Bunjilaka, meaning 'the place of Bunjil', the ancestral eaglehawk, in local Aboriginal languages.

At that time, Philip was a producer rather than a curator. ${ }^{27} \mathrm{He}$ worked on the new Indigenous exhibit, Bunjilaka, under three curators who were each responsible for their own distinct section: Aboriginal academic and writer Tony Birch (a member of the Melbourne Koori community ${ }^{28}$ ), who curated Koori Voices; senior curator of Northern Australia Lindy Allen, who curated Belonging to Country; and John Morton, an anthropologist specializing in Central Australia who was seconded from LaTrobe University for two years to curate Two Laws. The last section explored 'issues about Aboriginal law, knowledge and property'. ${ }^{29}$

Drawing on an idea of Tony Birch's, John Morton planned an ingenious climax for his section of the exhibition. In a reversal of the colonial gaze that placed Indigenous people and culture on display, a statue of Baldwin Spencer would be put in a glass case (Figure 2). The case was specially designed to 'parody the large exhibition cases often used in older museums' and stood 3.2 metres high and 12 metres across. ${ }^{30}$ Along with

27 He later completed a $\mathrm{PhD}$ in anthropology and returned to the museum in his current role.

28 'Koorie' (alternative spelling 'Koori') is a term for Indigenous people from Victoria. 'Indigenous' is a term for descendants of the pre-colonial peoples of Australia. Indigenous Australians are also known as 'Aboriginal and Torres Strait Islanders', a term that disambiguates Torres Strait Islanders from 'mainland' Indigenous Australians. The working definition of Indigeneity in Australia is self-identification, descent from an Indigenous person and Indigenous community acceptance.

29 'Indigenous cultures' brochure, c.1998, Museum Victoria archives.

30 Props and dressing brief, Bunjilaka, Melbourne Museum, 1999, Museum Victoria archives. 


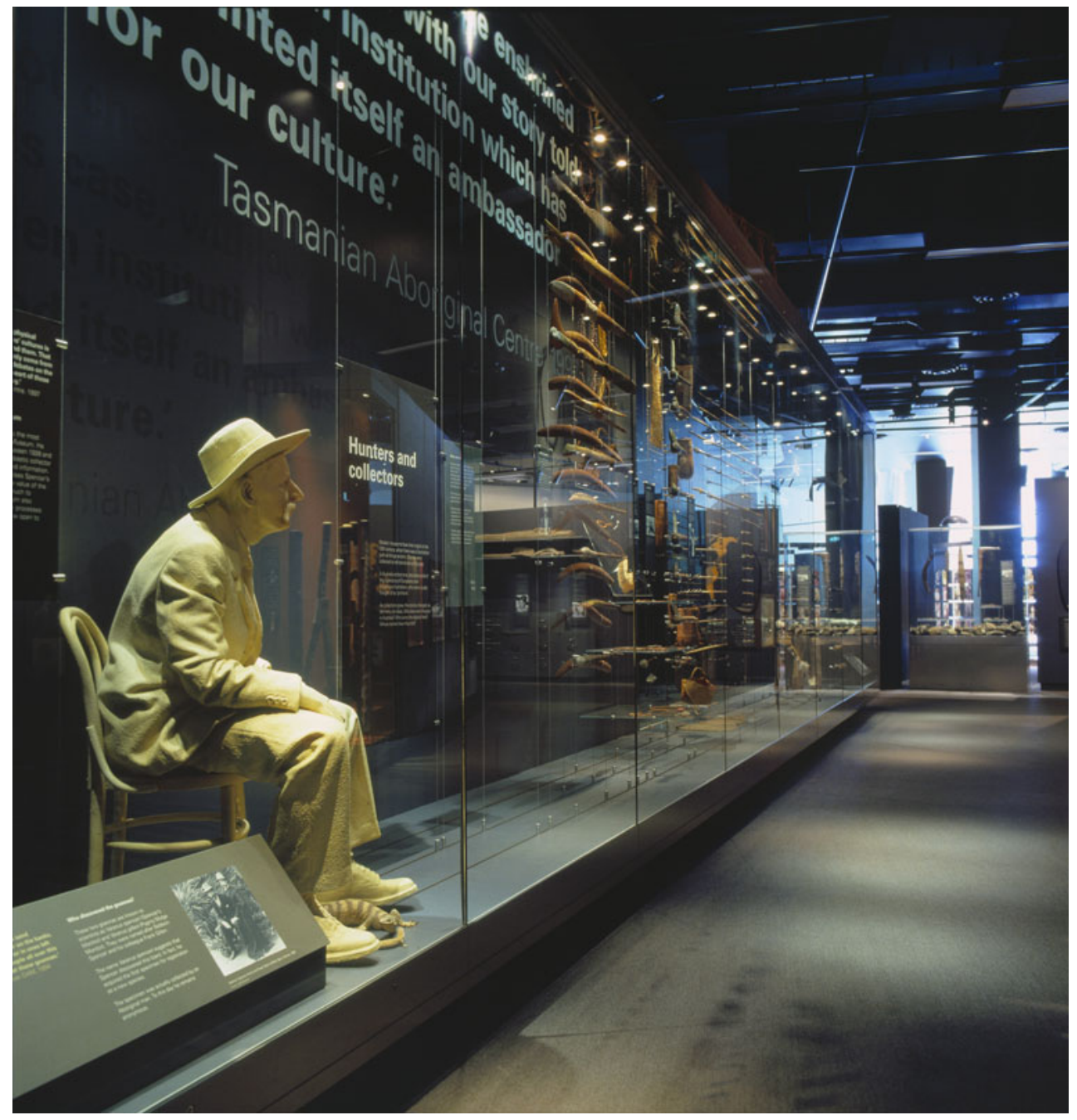

Figure 2. Model of Baldwin Spencer in the Two Laws exhibit, Bunjilaka, Melbourne Museum, 2000. Source: Museum Victoria.

Spencer, it contained 112 everyday objects that Spencer and his contemporaries collected, including spears and spear throwers, baskets, smoking pipes, digging sticks, knives, throwing sticks, clubs, neck ornaments and a canoe. This subsection of Bunjilaka, entitled Hunters and Collectors, ${ }^{31}$ had the statue of Spencer at its heart. He wore his usual fieldwork attire, seen in the 1901-1902 expedition photograph

31 This subtitle was taken from the title of a 1996 book on collecting in Australia (also the name of a famous 1980s band). See Tom Griffiths, Hunters and Collectors: The Antiquarian Imagination in Australia, Cambridge and Melbourne: Cambridge University Press, 1996. 
(Figure 1): a simple suit and tie, boots and a wide-brimmed hat, the long lines of his face accentuated by his signature moustache. At his feet were models of two goannas named for Spencer and his collaborator: Varanus Spencerii and Varanus Gilleni. ${ }^{32}$ Birch's original vision was of a performance piece where an Aboriginal curator would provide commentary on the encased anthropologist. Morton intended to realize this vision with a statue of Irrapmwe, Spencer's main Arrernte informant (otherwise known as King Charlie), standing outside the case peering in, but the idea was dropped by the designers for logistical and financial reasons. ${ }^{33}$

I remember seeing the model when the exhibition opened in the year 2000. Spencer's expression seemed somewhat bewildered, framed by a quote from the Tasmanian Aboriginal Centre that made the curatorial intention clear: 'We do not choose to be enshrined in a glass case, with our story told by an alien institution which has appointed itself an ambassador for our culture. 34 At a time when Indigenous museology was being reconsidered around the world, the model of Spencer aimed to promote Indigenous agency and a reflexive reading of history against the grain of colonial collecting practice. As explained by John Morton in a briefing document, 'In this way, the collector (Spencer), has been collected'. ${ }^{35}$ Enclosed in his glass case, he was also caught, captured 'so that you may scrutinise him (and what he stands for) along with the objects'. ${ }^{36}$ In a set of interlocking reversals, the audience was invited to 'study' Spencer's scientific methods and legacy and find them wanting, especially morally. As I explore later in the article, reviews of the exhibition indicate that, for many museum visitors, it achieved the intended effect.

The anthropology conference where Philip told me the strange story was in 2012 . He had spent the previous few years working on a major project to digitize thousands of objects and recordings collected by Spencer and Gillen. ${ }^{37}$ Philip and I share an interest in the politics of Indigenous-state relations and I pondered the irony of Spencer the statue trapped in his glass case while the objects he collected and created are granted unprecedented mobility on the Internet, all the while under strict Indigenous control through project protocols.

32 The label for the goannas shows how they were intended as another layer of post-colonial pedagogy. The label was entitled 'Who discovered the Goannas?' It told the audience, 'The name Varanus spencerii suggests that Spencer discovered this lizard. In fact, he acquired the first specimen for registration as a new species. The specimen was actually collected by an Aboriginal man. To this day he remains anonymous.' Photocopy of Label 53, c.1999, Museum Victoria Archives.

33 The idea was not lost completely. It was taken up in another part of the exhibition called Dialogue that consisted of a short film staging a conversation between Baldwin Spencer and Irrapmwe in which Irrapmwe chastises Spencer for not appreciating his status as a professor in his own culture, for writing derogatory things about Indigenous people and for displaying sacred objects in the museum.

34 Tasmanian Aboriginal Centre, 'Free exchange or a captive culture? The Tasmanian Aboriginal perspective on museums and repatriation', in Museums Association Seminar: Museums and Repatriation, 4 November 1997, London: Tasmanian Aboriginal Centre, Hobart, 1998, p. 21.

35 Props and dressing brief, Melbourne Museum, Lower East - Bunjilaka, 15 November 1999

36 Excerpt from text of Two Laws, 21 February 2000 version, electronic file, MV.

37 This website was launched the following year: http://spencerandgillen.net. 
Philip told me that Spencer was no longer in his case. ${ }^{38}$ That area of the museum had been rebranded as the Bunjilaka Aboriginal Cultural Centre. The permanent exhibit within the Cultural Centre had been completely redeveloped and was given a separate name - First Peoples - that distinguished it from the earlier Bunjilaka exhibition. Created in partnership with a group of local elders, it focused exclusively on Victorian Aboriginal people and Aboriginal perspectives. ${ }^{39}$ The Spencer statue was singled out as an example of what the First Peoples exhibit was trying to remedy. As an Indigenous curator commented, 'I'm not interested in the collectors at all'.

What had happened to Spencer? 'He's still in the museum,' Philip told me, although no longer accessible to the public. At the request of some staff, he had been retained and placed in a receipt room where objects were processed before being accessioned. He sat on a trolley, taking up considerable space in a narrow, windowless lab located between staff offices on one side and the museum stores on the other - between profane and sacred areas of the museum. It intrigued me to think of Spencer on his chair, on a trolley, watching over museum staff as they enveloped objects in the infrastructure of collection - describing, classifying, entering data, labelling, maintenance planning, risk minimizing.

A few years later I saw Philip again at a museum seminar. The conversation turned to Spencer - was he still on his trolley in the holding room? 'That's an interesting story,' he said. I was not prepared for what came next. At some point in the previous year, Spencer had been moved from the holding room to the 'restricted' room in the museum stores. Beginning in the 1980s, museums around Australia created restricted or 'secret/sacred' rooms where ceremonial objects that should not be seen by a general audience could be kept securely. ${ }^{40}$ Australian museums seek to repatriate these objects to the source communities, but because this is a long (sometimes decades-long) process, and because some communities request that museums retain possession (but not ownership) of their restricted objects, secure storage is needed. At the Melbourne Museum, this is a shed that sits within the museum stores. It is only accessed by the (white) manager of the restricted store, by Philip Batty, and by visiting elders from remote communities in Northern and Central Australia. Spencer sat in his trolley against the far wall, between the shelves. 'He's a bit spooky,' Philip told me, 'sitting there in the dark.'

38 For the remainder of the paper I refer to the statue as 'Spencer' and corresponding pronoun, following the naming practices of some museum staff (he was also called 'Baldy', short for Baldwin). While acknowledging that this risks anthropomorphizing a representation of a person, the technically incorrect terminology helps to explore my central question of what the model means to museum staff.

39 Richard Broome, Ian Hoskins, Kathy De La Rue, Shauna Bostock-Smith, Shirley Fitzgerald, Karen O’Brien and Alison Wishart, 'Exhibition reviews', History Australia (2014) 11(3), pp. 207-223, 207-209.

40 On the history of repatriation see Cressida Fforde, Jane Hubert and Paul Turnbull (eds.), The Dead and Their Possessions: Repatriation in Principle, Policy and Practice, London: Routledge, 2002; Kathleen S. FineDare, Grave Injustice: The American Indian Repatriation Movement and NAGPRA, Lincoln: University of Nebraska Press, 2002; Paul Turnbull and Michael Pickering, The Long Way Home: The Meaning and Values of Repatriation, Oxford: Berghahn, 2010. For an early example of a secret-sacred collection policy see South Australian Museum Board and South Australian Museum (issuing organization), Statement on the Secret/Sacred Collection, Adelaide: South Australian Museum, 1986. 
How did Spencer come to be sitting in the dark inside the restricted room, inside the museum stores, inside the museum offices, inside the museum? Philip wasn't clear on the details, and I didn't have time to probe him further. Another year went by, and I finally took time to email a senior manager at the museum to request permission to look into Spencer's story. Permission was granted, and I began combing through the archives of the exhibition.

Contemporary museums produce mountains of paperwork. Meetings are minuted, policies are revised and circulated, objects are tracked, exhibition incidents are noted and analysed. ${ }^{41}$ The paper traces of the Indigenous exhibit began with academic essays commissioned in the mid-1990s to provide intellectual guidance for those developing the new museum; ${ }^{42}$ proceeded through hazard reports, design plans and hundreds of pages of spreadsheets with lists of objects; and finally a memo announced the de-installation of the 'large Spencer showcase' - the very first part of the Bunjilaka exhibition to be dismantled - in June 2011.43

Two remarkable things about Spencer emerged from these thousands of documents, both of which underline his ambiguity. First, he is called many different things: a statue, a replica, a model, a prop, a mannequin, a set piece or an exhibition dressing. No one descriptor is more common than any other.

Second, Spencer is not visible in the exhibition management systems. ${ }^{44} \mathrm{He}$ appears on documents relating to concept development, in prop briefings and in plans of the exhibition. But once the exhibition was installed, Spencer disappears from any lists of display objects or props. The two goannas that sat at Spencer's feet are duly tracked through the entire exhibition and are a proxy for Spencer's archival presence. After de-installation they parted ways with Spencer and were transferred to Herpetology, depriving me of even this spectral trace of the statue's location.

Tracing the story of how Spencer came to be an unauthorized occupant of a highly restricted room became partly a question of regulation. His lack of official existence was frustrating to the present author, but was also an important determinant of his mobility. After de-installation in 2011, individual museum staff could take personal initiative in deciding his location without the scrutiny applied to tracked objects. In other words, he was especially amenable to collection because he was never intended to be collected. To understand why Spencer was not tracked, I needed to learn more about props.

At Museum Victoria, the Exhibition Collections Management (ECM) team are responsible for all items on display. These items can be classified into two groups: items from the museum collection (also called the state collection or heritage collection),

41 For example, possum droppings were found in a Bunjilaka display in June 2010.

42 For example, Tony Birch, The Recognition of Indigenous Rights in Museum Victoria, Melbourne: Museum Victoria, 1996; Chris Healy, Revisiting Histories and Mythologies, Melbourne: Museum Victoria, 1995.

43 Bliss Jensen, 'Phased closure of Jumbanna', electronic document, 17 June 2011, Museum Victoria archives.

44 For context on the institutional mechanics of museum exhibitions, including the management of props, see Barry Lord and Maria Piacente (eds.), Manual of Museum Exhibitions, 2nd edn, Lanham, MD: Rowman \& Littlefield, 2014. 
and props that are brought in to the museum specifically for an exhibition. Props can be items on loan (that must be tracked to ensure they are safely returned), items commissioned from an artist or a commercial prop maker, or items sourced by museum staff themselves. The division between museum collection items and props is not always visually obvious when they are on display (although a discerning visitor might notice that some items have corresponding labels and some do not). However, the exhibition management systems maintain a strict electronic separation between collection items and props, a division maintained in physical space through separate off-storage facilities for collection items and for props awaiting reuse.

A 2015 Museum Victoria information sheet on exhibition props gives three reasons for their use: 'to replace vulnerable collection items, - e.g. facsimile of old letter; to dress an exhibition case or display - e.g. replica jar of preserved fruit; to replicate unusual, rare or important items - e.g. painted cast of Tarbosuarus tooth'. ${ }^{45}$ These three reasons readily collapse into two: to replace or replicate something that cannot be shown directly (because it is too vulnerable or valuable to show, or because the museum does not have it) and the use of 'commonly found items and specimens' to provide decoration or illustration. ${ }^{46}$ Tellingly, Spencer doesn't fit into either of these categories.

Not all props are tracked with an ECM number. Many minor items like curtains and tables are sourced and recycled as required. The major goal of tracking props is to maintain 'a clear distinction between collection items and non-collection items'. ${ }^{47}$ A manager explained this to me by contrasting a purse bought from a charity shop and a purse in the collection that might look similar. 'If something can be confused with the heritage collection, if you anticipate things could get mixed up in the future, it will be tracked.' It was Spencer's singularity that kept him out of the ECM records. He could not be mistaken for any object in the collection, was not loaned from anyone and was not particularly valuable. ${ }^{48}$

This meant that there was no record of disposal at the time of de-installation. When an exhibition is over, items from the collection are simply returned to their home department. By contrast, props can meet one of several fates. They can be returned to their

45 Exhibition props information sheet, Exhibition Collection Management, Museum Victoria, electronic document, 21 May 2015, Museum Victoria.

46 In the Bunjilaka exhibit, the list of props included a facsimile of a list of rules for residents of Lake Tyers Mission, a quoll skin, and a teddy bear.

47 Exhibition props information sheet, op. cit. (45).

48 The Spencer model was made by a production company from an 'off-the-shelf' seated mannequin and a bentwood chair. The mannequin's head and hands were removed and replaced by fibreglass casts of Spencer's head and hands. The casts were created from clay sculptures created by in-house sculptor Peter 'Smiley' Williams from photographs of Spencer. Mannequin joints were fixed with fibreglass bandages and the costume department dressed it with starched clothing. The dressed model and chair were then sprayed with urethane to create an exoskeleton 1.5 millimetres thick. To finish the model, undercuts and fabric folds were filled with resin and the entire structure was painted with a sand-textured paint and darker highlights, forcing shadows in the folds. Interestingly, the production of the statue illustrates the history of prop creation: if it were produced now it would simply be 3D printed. Source: email to the author from John Kerr, creative director of Stage One Productions, 15 September 2017. 
source, they can be accessioned into the collection, ${ }^{49}$ they can become part of the 'handson collection' in the Discovery Centre for handling by the public, they can be distributed to whoever wants them, ${ }^{50}$ or they can be destroyed. Again, Spencer defies all of these categories. He was retained but not accessioned; disposed not to one person, but to a loose collective of staff. Staff could only vaguely remember the meeting when the fate of Spencer and all the tracked props were discussed, and no minutes were taken. No single person claimed responsibility for the idea to informally collect him, but all those I spoke to were supportive of the decision. Looking back, staff thought the reasons he was retained were that 'a lot of work has gone into it', 'it's a historical object' marking 'the moment of the exhibition', and 'people have grown attached to him'. Others denied any particular intention or meaning to his retention: 'some things get salvaged, some get ditched. It was an off-the-cuff decision'. ${ }^{51}$

Whatever happened at the disposal meeting, it is clear that after June 2011, Spencer was moved to the receipt room (as I have described). No one I spoke to could offer a clear reason or timeline for his next move to the restricted room. The best explanation I heard was that the lab had to be emptied while LED lights were installed. Suddenly homeless, the restricted room was seen as a safe place for Spencer, 'out of the way but protected'. Staff give conflicting accounts as to how long he was in the room, with responses ranging from several years to two weeks. I noted (without surprise) that my questions about why and how long he was in the room were often taken defensively, despite my best efforts to be casual. 'It was just a spot to put him', I was told. My anthropological sensibility was never going to be assuaged by reassurances that Spencer's placement in the restricted room meant nothing. Of course, this 'just' heightened my belief that it meant quite a lot.

\section{From post-colonial prop to decolonial ghost}

Ever since Bunjilaka opened in the year 2000, Spencer has asserted his significance. Despite being a mere prop, outside the bounds of museum collection proper, he is universally mentioned in reviews and critiques of the exhibition. ${ }^{52}$ Academic reviews appreciated the intended meaning of Spencer as a post-colonial pedagogical tool that inverted the power relations behind the formation of the museum and its collections. They applauded the 'impressive' and 'brilliant' Two Laws section as the 'first time that a major museum in Australia has confronted its past to address the ethics of collecting

49 This pathway is used by curators to obtain contemporary art and craft works by Indigenous artists - they are commissioned as props but with the unofficial intention to accession them at the end of the exhibition.

50 For example, a pen marking on a spreadsheet of tracked props indicates that the teddy bear 'went to a good home'.

51 Quotes in this paragraph are taken from personal communications with museum staff.

52 John Morton, "'Such a man would find few races hostile”: history, fiction and anthropological dialogue in the Melbourne Museum', Arena Journal (2004) 22, pp. 53-71. The prominence of Spencer in the reception of the exhibition attests to the agency of objects and their chronotopic potency (see Roque, this issue; Jardine, Kowal and Bangham, this issue). 
and constructing non-Indigenous versions of Aboriginal history and culture' ${ }^{53}$ In contrast with the warm reception offered by academics and progressive media outlets, the Australian right-wing press was predictably outraged at the indignity of putting Spencer on display. The museum was called a 'politically correct Aboriginal gallery' pushing 'propaganda' that sullied the good name of its founding fathers. ${ }^{54}$

Writing in 2004 in response to various criticisms of the exhibition, John Morton argued for its pedagogical legitimacy and its relevance to contemporary political debates, but also made the point that it was intended for Aboriginal audiences as much as for the wider public, if not more so. Bunjilaka was the result of 'extensive community consultation' regarding every part of the exhibition. ${ }^{55}$ But the extensive community involvement did not guarantee that all Aboriginal people would endorse the result. As John Morton told me, some Aboriginal staff looked on the statue of a scientist in a glass case with suspicion. The intended purpose of collecting the collector did not resonate with them. Why was Spencer at the centre, again? They would prefer not to think about the collectors at all..$^{56}$

When the Bunjilaka exhibition was succeeded by First Peoples in 2011, the Spencer statue was removed from public display. The publicly stated rationale for First Peoples contained an implicit reference to the presence of white collectors in the previous exhibition. The lead curator, Genevieve Greives, explained the process of creating an elders' group to co-curate the new exhibition as creating 'new structures which gave authority back to the people who owned the objects and the stories. We tried to make sure stories were not divorced from their owners and voices were not silenced'. 57 The website text for the exhibition explained that the First Peoples exhibit 'presents the Koorie [a general word for Aboriginal Victorian] experience with immense power, depth and respect in a major permanent exhibition entirely co-created with Aboriginal people' ${ }^{58}$

I interpret Spencer's decommissioning as part of the broader cultural shift inside and outside museums towards decoloniality. As discussed above, decoloniality is often seen in opposition to post-colonialism, and as its successor. I see this dichotomy reflected in some museum studies literature as two models of exhibition: the 'multivocal exhibition model', a model I associate with the post-colonial, and the 'community-based model', one I associate with decolonial approaches. Native American museum studies scholar Amy Lonetree describes a multivocal approach as characterizing

the effort by the more progressive museums of the 1990s to deal more fairly with [topics related to Indigenous people]. When museum professionals were faced with presenting sensitive topics,

53 Anne Delroy, 'Reviews: exhibitions', Australian Historical Studies (2001) 32(116), pp. 147-150. Lynette Russell, 'Bunjilaka brooding', Meanjin (2001) 60(4), pp. 99-103.

54 Andrew Bolt, 'A museum of spin', Herald Sun, 20 November 2000, cited in Russell, op. cit. (53), p. 99.

55 Morton, op. cit. (52), p. 67.

56 John Morton, personal communication, 20 January 2017.

57 Museums and Galleries of NSW, 'At home: Genevieve Grieves', Museums and Galleries of NSW, 18 February 2015, at https://mgnsw.org.au/articles/home-genevieve-grieves, accessed 7 April 2018, emphasis added.

58 Museum Victoria website, https://museumsvictoria.com.au/bunjilaka/about-us, accessed 7 April, 2018, emphasis added. 
especially those of a more controversial nature, they would present a range of perspectives and leave it to visitors to weigh the value of each. ${ }^{59}$

The community-based model, in contrast, strives to privilege the Indigenous community's view of an object or collection over other possible views (of curators, scientists or others). In a decolonial, 'indigenized' museum, exhibitions and curatorship should be controlled by Indigenous people because 'controlling the representation of their cultures is linked to the larger movements of self-determination and cultural sovereignty.' 60

Lonetree describes her own passage from a post-colonial, multivocal approach to a decolonial, community-based one through a story of her curatorial practice. At the time, she was working for the Minnesota Historical Society developing the new Mille Lacs Indian Museum that opened in 1996. In constructing a draft of the historical timeline of the Mille Lacs, Lonetree used a multivocal exhibit model to present Mille Lacs accounts of their origins alongside scientific accounts of population expansion across the Bering Strait. She was 'firmly' castigated by community members who told her, 'We do not care what other people say about our origins. We want to feature only our story.' Similarly, Lonetree sees museum objects as 'living entities that remain intimately and inextricably tied to their descendant communities', and that can only be interpreted by these communities, facilitated by museum staff who are also preferably Indigenous. ${ }^{61}$ This applies equally to contemporary Indigenous Australian museum practice. ${ }^{62}$

Given this context, it is not surprising that, by 2011, Spencer's double no longer had a place in Bunjilaka. Although the idea was conceived by an Indigenous scholar (Tony Birch), it was widely considered by museum staff to be a 'non-indigenous' object. Birch's idea was implemented, and the statue constructed, by non-indigenous people. Spencer in a glass case was a product of 1990s post-colonial, satirical, multivocal museum practice, and his end had come. This suggests that the passage from post-colonial to decolonial approaches means that collectors no longer have a place in Indigenous museum collections, even as a focus of critical reflection. In the case of Spencer, his exile from the exhibition marked other shifts that had uneven effects on different groups of Indigenous people.

We can see this in the quote a few paragraphs above in which Grieves explains the focus of the First Peoples exhibit that succeeded the first iteration of Bunjilaka. When she talks about creating structures that 'gave authority back' to the owners, she arguably

59 Lonetree, op. cit. (21), pp. 169-170. The terminology of 'multivocal' and 'community-based' derives from Ruth B. Phillips, Museum Pieces: Toward the Indigenization of Canadian Museums, Montréal: McGill-Queen's University Press, 2011.

60 Lonetree, op. cit. (21), p. 1. On the 'indigenized museum' see Moira G. Simpson, 'Revealing and concealing: museums, objects, and the transmission of knowledge in Aboriginal Australia', in Janet Marstine (ed.), New Museum Theory and Practice: An Introduction, Malden, MA: Blackwell, 2006, pp. $152-177,174$.

61 Lonetree, op. cit. (21), pp. 169, xv.

62 Sandy O'Sullivan, 'Recasting identities: intercultural understandings of first peoples in the National Museum Space', in Pamela Burnard, Elizabeth Mackinlay, and Kimberly Powell (eds.), The Routledge International Handbook of Intercultural Arts Research, Abingdon: Routledge, 2016, pp. 35-45; Simpson, op. cit. (60). 
refers to the traditional owners of Victoria - Koorie people - and not the owners of the objects in the museum. The vast majority of the Aboriginal collection is made up of objects from Central and Northern Australia, with only a small fraction from Victoria. Although the extensive inclusion of remote Indigenous stories in the first Bunjilaka exhibition (particularly the Belonging to Country and Two Laws sections) accurately reflected the museum's holdings, the focus of two out of three of Bunjilaka's sections on Indigenous people outside Victoria was increasingly seen as a problem. Acknowledging the embeddedness of Indigenous people in the land and the importance of reclaiming Indigenous control of their heritage, by the end of the 2000s many Indigenous curators felt the Melbourne museum should stick to telling stories about local Koorie communities.

In their eyes, putting Spencer in a glass case was another way to put him on a pedestal. Was the mood lighting, intended to create solemnity and reflection, really a white people's shrine to our revered scientist? Spencer's model, hollow plastic underneath the sand-textured paint, was technically silent. But his form spoke volumes, and was interpreted as silencing Indigenous voices. John Morton, and certainly Tony Birch, intended for it to be ironic and not reverential, but it could be read either way.

This analysis highlights how, at the Melbourne Museum, the shift from 'multivocal' post-colonial to univocal decolonial museology worked to silence not just non-indigenous voices, but also non-local indigenous voices. Prior to the decolonial shift, the national responsibility of an institution like Museum Victoria to Aboriginal people beyond Victoria's borders was clear, and the importance of the museum's relationships with Indigenous communities in Northern and Central Australia was taken for granted. Some museum staff believe this is no longer the case. This reflects in part the fact that it is exclusively non-indigenous people that currently work with remote-community collections. There are no Indigenous museum staff who are from the communities that have objects in the restricted room - the place where Spencer's double eventually found a home - so while Indigenous visitors and non-indigenous staff frequent the room, Indigenous museum staff do not pass its threshold. With the decolonization of the museum and the subsequent focus on Koorie communities, the objects and communities that are represented by the vast majority of museum holdings have become relatively invisible. The presence of Spencer's double in the restricted room demonstrates both the attempt to exile certain voices from the decolonial museum and the enduring power of that which is repressed but which stubbornly surfaces in ghostly forms.

\section{De/collecting Spencer}

Spencer's double embodies the strengths and the vulnerabilities of the post-colonial and decolonial eras. In his time in the glass case, he resembled a Rankian double. He functioned as a cathartic 'bad' object for progressive museum professionals, academics and visitors. To gaze at Spencer in the glass case produced a satisfactory sense of irony and historical distance from the days when the sacred objects of Indigenous peoples, and even Indigenous people themselves, were collected and circulated for the 
edification and entertainment of Western publics. ${ }^{63}$ In place of the dioramas depicting Aboriginal people in 'traditional' scenes that were standard museum fare well into the twentieth century, the white audience is invited to gaze at Spencer. If Spencer is in the case and we are outside the case looking at him, then we cannot be Spencer. The glass between us promises we are different - progressive, anti-racist, post-colonial or even decolonizing. ${ }^{64}$

Despite John Morton's claim that the first Bunjilaka exhibit was primarily aimed at Indigenous audiences, the post-colonial mode of exhibition actively sought to cultivate progressive and reflexive non-indigenous identities. As that mode of collection and exhibition ended around 2010, so did the place for non-indigenous people, disparaging Spencer from outside the glass. In the decolonial era, non-indigenous allies are encouraged to stay silent and try to not take up any space. ${ }^{65}$ The local Indigenous critiques of the 'white guy' taking up space in the Indigenous museum exhibit, and the political shifts these critiques represented, were more or less well known to non-indigenous museum staff at the time of Spencer's deinstallation in 2011. How, then, should we understand his retention in the 'backstage' of the museum? ${ }^{66}$ And how do we interpret his later move to the restricted room?

Once Spencer was released from his case and became an honorary museum object (perhaps even an honorary staff member), the Rankian relationship between the nonindigenous viewer and Spencer's double was undone. What exactly he became then is up for debate and I do not claim to have the definitive answer. But I am convinced that part of what he meant to non-indigenous museum staff is captured in the notion of nostalgia, that many-layered relation to things in our past. ${ }^{67}$ Spencer the ironic post-colonial statue embodied a particular chronotope: a particular time, place and politics. ${ }^{68}$ The time was a period in the recent history of collections, approximately 1990 2010, and the place was Australia and other similar settler colonies, particularly Aotearoa/New Zealand, Canada and the United States. The politics that Spencer embodied was a period when Indigenous interests in - if not outright ownership of their heritage was firmly established, but some non-indigenous people still had relatively unquestioned roles - significant, positive and public roles - in telling Aboriginal stories.

63 See Sadiah Qureshi, Peoples on Parade: Exhibitions, Empire, and Anthropology in Nineteenth Century Britain, Chicago: The University of Chicago Press, 2011.

64 For scholarship on Australian white anti-racism see Kowal, Trapped in the Gap, op. cit. (9); Ahmed, op. cit. (10).

65 Note that what I explain here as a shift from post-colonial to decolonial could also be told through the lens of whiteness studies, the academic study of white privilege that boomed in the 1990s but has shrunk in influence, partly due to critiques that being self-reflexive about white privilege is itself a form of white privilege. Being silent is sometimes proposed as a better strategy for white people. For an Australian example see Nado Aveling, "'Don't talk about what you don't know”: on (not) conducting research with/in Indigenous contexts', Critical Studies in Education (2013) 54(2), pp. 203-214.

66 'Backstage' is meant in Goffman's sense. See Erving Goffman, The Presentation of the Self in Everyday Life, New York: Anchor Books, 1959.

67 On nostalgia see Svetlana Boym, The Future of Nostalgia, New York: Basic Books, 2001.

68 Mikhail Bakhtin, 'Form of time and chronotope in the novel', in Bakhtin, The Dialogic Imagination: Four Essays, Austin: University of Texas Press, 1981, pp. 84-258. For an application of the concept of chronotope see Roque, this issue. 
The Rankian projection that helped maintain the possibility of white anti-racism was difficult to relinquish, and keeping Spencer was a coping strategy.

Spencer's uncased double was more than a focus of nostalgia for post-colonial times. He also took on uncanny dimensions, especially when he entered the restricted room. Spencer became the vessel for voices that are silenced in the univocal, decolonial museum, voices including those of non-indigenous and non-local Indigenous actors. This analysis raises a critique of 'community-based' models of museum practice as articulated by Lonetree and other decolonial scholars. As many others have observed, the idea of a singular, uncomplicated 'Indigenous community' is a fantasy, especially where state or national institutions are concerned. Privileging 'the Indigenous community' necessitates delineating who and what the community consists of, a decision that will inevitably marginalize some Indigenous people. ${ }^{69}$

The hope of the decolonial museum is that local Indigenous voices are allowed to speak without distortion. Yet the presence of Spencer's double in the restricted room illustrates how decolonial approaches may struggle to stifle the many voices that found expression in previous modes of collection. Regardless of the decolonial intentions of museums, repressed traces of past collectors and curators remain embedded in the objects they handled, considered, collated, described and displayed. This can be seen as the failure of decolonization, remediable through greater efforts to still those stubbornly persistent colonial voices. Spencer's end was deferred by people - non-indigenous staff members at the museum - who placed him in the receiving room and then the restricted room. If those people were better trained in decolonial museology, the argument might go, they would not have done this without the specific direction of the Indigenous community.

However, the persistence of Spencer contains important lessons for decolonial museological practice that may be missed if the episode is solely attributed to incomplete decolonization or even racism. An alternate reading I offer is that Spencer's uncanny, obstinate double shows us how the difficult histories of objects cannot be disembedded. Spencer is part of the thousands of objects he collected and cannot be extricated, whether or not Indigenous or non-indigenous curators or community members are interested in his influence. Spencer's model is now also part of the difficult history of Indigenousmuseum relations. ${ }^{70}$ Efforts to silence certain museum histories run the risk of promoting ghostly presences, ${ }^{71}$ even when these efforts are grounded in morally and politically sound principles. Thus Spencer's decommissioning is symptomatic of the decolonial turn, but Spencer's failure to end is symptomatic of the decolonial turn's internal tensions and contradictions.

69 For an Australian example see Frances Peters Little, The Community Game: Aboriginal Self-Definition at the Local Level, Canberra: Australian Institute of Aboriginal and Torres Strait Islander Studies, 1999.

70 Sharon Macdonald, Difficult Heritage: Negotiating the Nazi Past in Nuremberg and Beyond, London: Routledge, 2009; Bain Attwood, 'Difficult histories: the Museum of New Zealand Te Papa Tongarewa and the Treaty of Waitangi exhibit', Public Historian (2013) 35(3), pp. 46-71.

71 Avery Gordon, Ghostly Matters, Minneapolis: University of Minnesota Press, 1997; Gordon, 'Some thoughts on haunting and futurity', Borderlands (2011) 10(2), pp. 1-21. 
Collecting Spencer in the restricted room reunited him with the objects he collected. Seated on his chair, on his trolley, between the shelves, he was shrouded in darkness save for rare occasions when museum staff or visiting remote-community members entered the room and turned on the lights. Staff told me that both they and community members were startled by Spencer's gaze: 'you get a shock; it's unsettling'. 'Most community members do not recognize him, but it makes sense to people that he is there when you explain who he is,' I was told. Tony Birch also told me that visiting Indigenous community members approve of Spencer's presence, watching over their sacred objects. ${ }^{72}$

Restricted rooms in Australian museums are a kind of shrine to a form of knowledge that Western scientists believed was on the verge of extinction from almost the first moment of contact. In his lifetime, Spencer the man sought to remedy this supposed demise by protecting Indigenous people and culture through isolation on reserves. ${ }^{73}$ The critically important efforts of the contemporary museum to counter the fallacy of extinction and promote living Koorie cultures may ironically be marginalizing other Indigenous knowledges all over again. In a sense, Spencer belongs in this dark pseudoshrine, a spectral presence eluding museum categories and databases, a mascot for a mode of post-colonial politics whose time has passed but that refuses to end. ${ }^{74}$

It remains to be seen how the history of science will engage with decolonial scholarship and vice versa. However, this article suggests that non-indigenous historians of science have an uneasy role in the decolonial museum. The stories that historians of science wish to tell about collections and collectors may not be welcomed by Indigenous curators. Undoubtedly, some historians of science will staunchly defend their perspectives, while others will adapt. In the next few years it will become clearer what a decolonial history of science looks like, both in museums and in academia, and historians of science who identify as Indigenous will play a critical role. In navigating the road ahead, we would do well to attend to the doubles of earlier eras of knowledge production, lest they haunt us.

\section{Epilogue}

On my first archival visit to the museum in February 2017, I was taken to see Spencer. Earlier that day I had sat in the office of the manager of the department explaining my interest in the story of the statue. Like many of the older curatorial staff, he was an academic and was sympathetic to my project. He confirmed that Spencer was stored in the restricted room, a place where, as a woman, I was obviously not permitted. 'We've taken him out so you can view him,' he said with a grin. 'You're going to love where he is now.'

Later a curator with access to the restricted room came to pick me up at the desk I had been allocated for the day. I followed him through the open-plan office, through the

72 Tony Birch, personal communication, 1 November 2017.

73 Many of these reserves eventually became what are now called 'remote communities', which in turn have been criticized by conservative politicians as 'cultural museums'.

74 This terminology was suggested by Tony Birch, personal communication, 1 November 2017. 


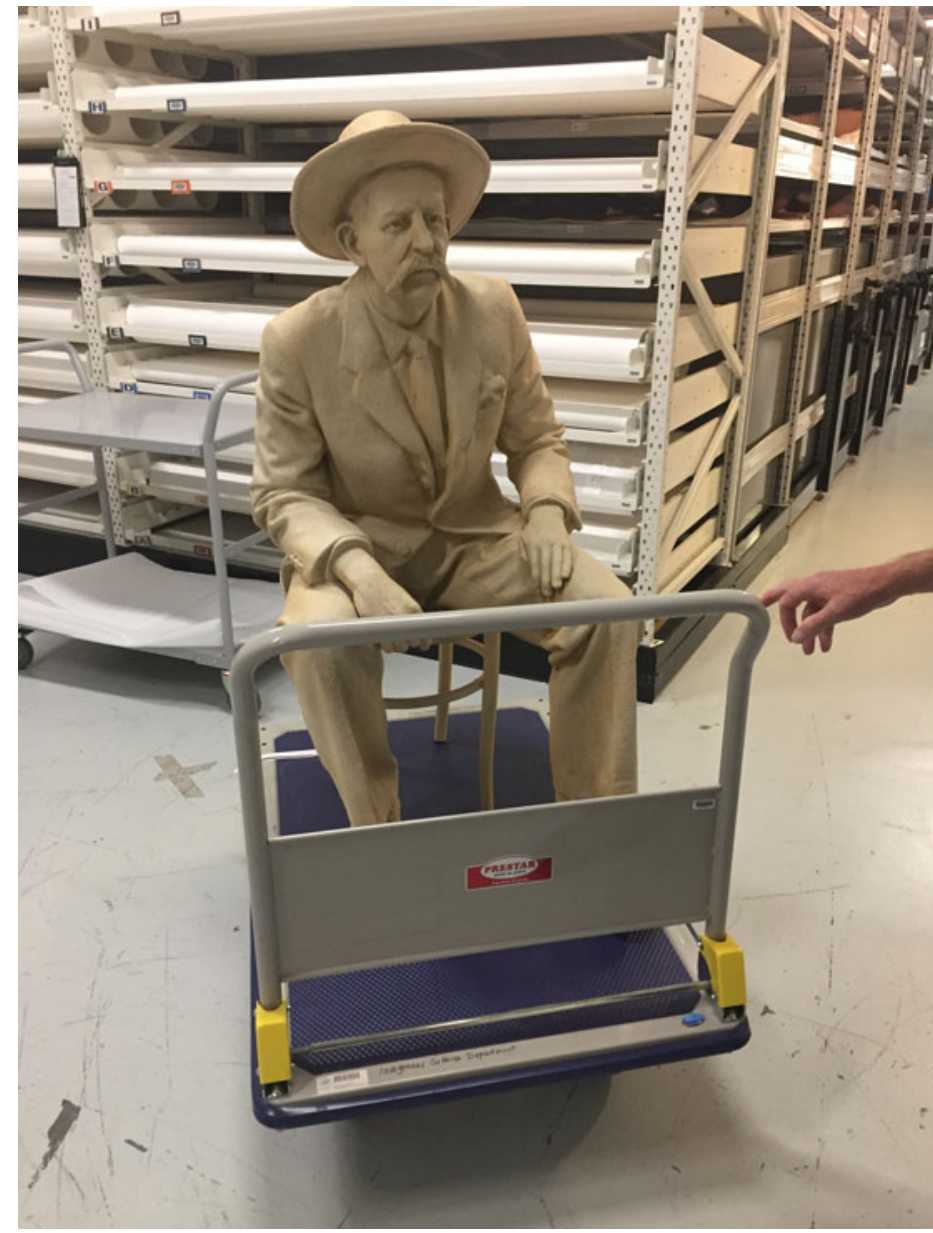

Figure 3. Spencer's model on a trolley in the museum stores, 2017. Source: Emma Kowal.

holding room where the statue had spent a few years, and into the museum stores. At each stage, his swipe card gave us access. The stores felt like a suburban library, packed with rows of shelves that held objects instead of books.

He gestured towards the first aisle on my right and I peered between the shelves. Spencer was there, facing me on his trolley, with a large painted Papuan statue towering over him. Another disturbing and humorous juxtaposition. The Papuan statue was a sacred object and I was not permitted to photograph it, so the store manager rolled Spencer's trolley out of the aisle and into the corridor, close to the door (Figure 3). We looked at Spencer together. 'I've got quite attached to him,' he reflected. 'I'm disappointed we don't have Gillen as well.' I asked him how Spencer came to be in the restricted store and he referred me to another staff member for an explanation. 
Seeing that he didn't want to talk about Spencer, I set about photographing the statue. I circled him to catch different angles of his face, then moved the trolley slightly to make room to capture the whole figure in one frame. But Spencer rolled towards me, escaping my gaze. I pushed him back. He rolled towards me again. I put my foot out to steady the trolley long enough to take the photograph, but I couldn't get far enough away to fit him in the frame. The curator came to the rescue, placing his finger on the trolley. Spencer was finally stilled and I got my shot.

I asked to see the outside of the room where Spencer is usually kept, and I was led down a corridor to what looked like a shed, painted grey with 'restricted' on the door. Some photographs of Spencer and Gillen, and photographs they took, hung on the outer walls. Pride of place among them was the expedition shot from 1901-1902 (Figure 1). As I photographed the framed photograph, the curator standing behind me seemed to shift into a reflective mode. 'He and Gillen knew those old people so well, they trusted him with their objects. It is right that he is in there with the things he collected.'

Since my first archival visit, Spencer has not returned to the restricted store. His place in the main stores between two aisles, below the Papuan statue, has become semi-permanent. Outside the restricted room he is more visible. A manager of another museum department I spoke to was 'quite surprised to see it in the store, I just saw it two days ago'. The future of the statue is now a subject of greater discussion among collections management staff who dislike ambiguous items. Spencer's large dimensions make him particularly vulnerable. Pressure to decide his fate is increasing. 'We're running out of storage space,' I was told, 'and we need to think carefully.'

There are essentially two ways to resolve Spencer's ambiguity: accession or disposal. In some of my conversations with staff, I discussed the possibility of accessioning Spencer. He would become part of the official collection, with a number, a description and a preservation plan. One of the departments would have to propose this and argue the case at a monthly acquisition meeting. I found myself collecting reasons why he should be accessioned. I was told the History of Collections curator might be interested in recording the statue's history, but she was never at her desk when I looked for her. When I brought it up with a manager who could potentially take on the accession, she was doubtful. 'It's not an object made by Indigenous people.' But she left open the possibility. 'Something is forming about the meaning of this object,' she mused. 'We must be applying some level of value because we haven't destroyed it.' I was now part of this growing web of significance enveloping Spencer, perhaps creating a legitimate place for him in the decolonial museum. How it ends will depend on the kind of value that he is accumulating and how far it can travel. 